\title{
Recent Trends in Extraction Techniques for High Value Compounds from Algae as Food Additives
}

\author{
Saniye Akyıl ${ }^{1}$, Işıl İlter ${ }^{1}$, Mehmet Koç², Figen Kaymak Ertekin ${ }^{1^{*}}$ \\ ${ }^{1}$ Department of Food Engineering, Faculty of Engineering, Ege University, 35100 Bornova/İzmir, Turkey \\ ${ }^{2}$ Department of Food Engineering, Faculty of Engineering, Adnan Menderes University, 09010 Aydin, Turkey \\ A R T I C LE IN F O

\section{Review Article} \\ Received 08 March 2018 \\ Accepted 13 July 2018 \\ Keywords: \\ Algae \\ Bioactive compounds \\ Green extraction \begin{abstract}
A B S T R A C T
Algae have been considered as a source of high value bioactive compounds including pigments, lipids, fatty acids, polysaccharides, antioxidants and minerals. These compounds serve as a source of nutrition for both humans and animals and as additives in food production. Conventional solvent and/or green extraction techniques are mostly applied to extract these compounds from algae biomass. In this review, paper the most frequently used green extraction techniques such as supercritical fluid extraction, microwave assisted extraction, ultrasound-assisted extraction, pressurized liquid extraction, subcritical water extraction and pulsed electric field extraction were investigated in terms of their process conditions, applications, advantages and
\end{abstract} \\ disadvantages.
}

Extraction techniques

Food additives

\footnotetext{
*Corresponding Author:

E-mail: figen.ertekin@ege.edu.tr
}

DOI: https://doi.org/10.24925/turjaf.v6i8.1008-1014.1895

\section{Introduction}

Most of algae have higher photosynthetic efficiency and faster grow rate compared to plants. They can be cultivated in large scale and do not necessarily need clean water to grow (Eriksen, 2016). Recently, the number of studies on algae has considerably increased in literature due to their bioactive compounds used as natural food colorants, antioxidants and antimicrobials (Barba et al., 2016; Plaza et al., 2012). In addition, algae are considered as a source of fatty acids, carbohydrates and proteins. But, the production of algae based bioactive compounds is not as widespread as desired. In order to achieve economically feasible production levels, more efficient and low cost downstream processing methods of bioactive compounds from algae should be design, because these downstream processes are generally accounts for the majority of manufacturing cost (Yen et al., 2013). Firmly identified with this point, the sustainability of the extraction and purification process is critical. Nowadays, the extraction process should be effective in terms of high extraction yield and environmental friendly. These new improvements are obviously required to agree with the Green Chemistry standards for extraction (Chemat et al., 2012): innovation by determination of renewable resources; use of alternative solvents, mostly water; generation of co-products rather than wastes; lessening of unit operations and apply non-denatured, biodegradable extracts without contaminants.
The high value compounds of algae generally take in intracellular vacuoles and chloroplasts, thus making extraction is difficult (Cuellar-Bermudez et al., 2015). Up to now, solid-liquid solvent extraction techniques have been mainly used to extract these compounds. However, the difficulty of these extraction methods are needed long time and high volume organic solvents that are most frequently toxic (Kadam et al., 2013), besides high laborious, low selectivity and/or low extraction yields. Because of this case, the researchers in this area have tried to develop new extraction processes which are aimed to be fast for time saving, high selectivity to desired compound, efficient, sustainable, green (without using toxic organic solvents), low cost, to obtain valuable products from algae rather than using traditional extraction techniques. Supercritical fluid extraction (SFE), pressurized liquid extraction (PLE), subcritical water extraction (SWE), microwave assisted extraction (MAE), ultrasound-assisted extraction (UAE) and pulsed electric field extraction (PEF) techniques answer those purposes. The extracted high-value compounds from algae and benefits of different green extraction methods are summarized in Table 1 and these innovative and effective extraction techniques have been reviewed in this study. 
Table 1 Green extraction techniques of algal biomass.

\begin{tabular}{|c|c|c|c|}
\hline Method & High value compounds & Algae species & $\begin{array}{c}\text { Utilities of extraction } \\
\text { method }\end{array}$ \\
\hline SFE & $\begin{array}{l}\text { Astaxanthin, chlorophyll-a } \\
\text { Carotenoids, chlorophyll-a } \\
\text { Carotenoids } \\
\text { (canthaxaothin, } \\
\text { astaxanthin), lipids } \\
\text { Vitamin E }\end{array}$ & $\begin{array}{l}\text { Monoraphidium sp. } \\
\text { Dunaliella salina } \\
\text { Chlorella vulgaris } \\
\text { Spirulina platensis } \\
\text { Chlorella vulgaris, Sargassum hemiphyllum, } \\
\text { Hypnea charoides, Spirulina platensis }\end{array}$ & 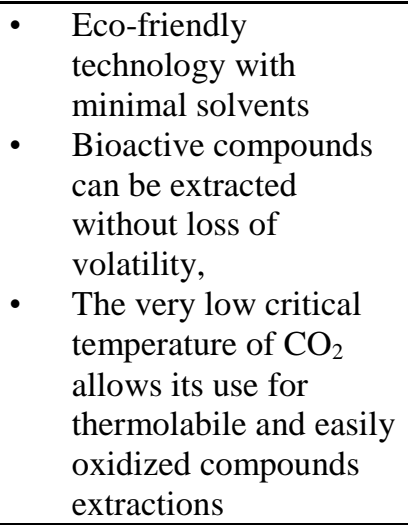 \\
\hline PLE & $\begin{array}{l}\text { Fucoxanthin } \\
\text { Zeaxanthin } \\
\text { Carotenoids } \\
\text { Short-chain fatty acids }\end{array}$ & $\begin{array}{l}\text { Phaeodactylum tricornutum } \\
\text { Chlorella ellipsoidea } \\
\text { Chlorella vulgaris, Dunaliella salina, } \\
\text { Neochloris oleoabundans, Haematococcus } \\
\text { pluvialis } \\
\text { Haematococcus pluvialis }\end{array}$ & $\begin{array}{ll}\text { - } & \text { Reduces the quantity of } \\
\text { solvents } \\
\text { - } & \text { Short operating time } \\
\text { Elevated temperature } \\
\text { and pressure } \\
\text { - } \begin{array}{l}\text { More flexible than } \\
\text { other methods }\end{array}\end{array}$ \\
\hline SWE & $\begin{array}{l}\text { Antioxidant } \\
\text { Antimicrobial agents }\end{array}$ & $\begin{array}{l}\text { Haematococcus pluvialis, Chlorella vulgaris, } \\
\text { C. abiesmarina, Porphyra sp.; S. vulgare, S. } \\
\text { muticum, Undaria pinnatifida, H. incurvus }\end{array}$ & $\begin{array}{ll}\text { - } & \text { Eco-friendly } \\
\text { technology with using } \\
\text { water as the solvent } \\
\text { - } \quad \text { Low amounts of } \\
\text { solvent } \\
\text { - } \begin{array}{l}\text { Safe, rapid, efficient } \\
\text { extraction }\end{array} \\
\text { - } \begin{array}{l}\text { High quality of the } \\
\text { extracts }\end{array} \\
\end{array}$ \\
\hline UAE & $\begin{array}{l}\text { Carotenoids, chlorophyll-a } \\
\text { Docosahexaenoic acid } \\
\text { Major, minor, and trace } \\
\text { elements }(\mathrm{Ca}, \mathrm{K}, \mathrm{Na}, \mathrm{Mg} \text {, } \\
\mathrm{Cd}, \mathrm{Cr}, \mathrm{Cu}, \mathrm{Mn}, \mathrm{Ni}, \mathrm{Pb} \text {, and } \\
\mathrm{Zn}) \\
\text { Lutein }\end{array}$ & $\begin{array}{l}\text { Dunaliella salina } \\
\text { Crypthecodinium cohnii } \\
\text { Porphyra sp.; Palmaria sp.; Undaria } \\
\text { pinnatifida, Himanthalia elongata, Laminaria } \\
\text { ochroleuca } \\
\text { Chlorella vulgaris }\end{array}$ & $\begin{array}{ll}\text { - } & \text { Low amounts of } \\
\text { solvent } \\
\text { - } \\
\text { Increased extraction } \\
\text { yield and faster kinetics } \\
\text { - } & \text { Extraction of heat- } \\
\text { sensitive compounds } \\
\text { with minimal damage } \\
\text { Easy to combine with } \\
\text { other methods }\end{array}$ \\
\hline MAE & $\begin{array}{l}\text { Iodine, bromine } \\
\text { Phenols } \\
\text { Phytosterols and phytol } \\
\text { Pigments } \\
\text { Polysaccharides }\end{array}$ & $\begin{array}{l}\text { Crypthecodinium cohnii } \\
\text { Fucus vesiculosus } \\
\text { Laminaria japonica, Undaria pinnatifida, } \\
\text { Sargassum fusiforme } \\
\text { Porphyra sp.; Palmaria sp.; Undaria } \\
\text { pinnatifida, Himanthaliaelongate, Laminaria } \\
\text { ochroleuca, Ulva rigida } \\
\text { Caulerpa racemosa } \\
\text { Undaria pinnatifida, Sargassum fusiforme } \\
\text { Dunaliella tertiolecta, Cylindrotheca } \\
\text { closterium } \\
\text { Enteromorpha prolifera }\end{array}$ & $\begin{array}{ll}\text { - } & \text { Fast, improved } \\
\text { extraction rate } \\
\text { - } \\
\text { Reduced extraction } \\
\text { time } \\
\text { Low amounts of } \\
\text { solvent and cost } \\
\text { effective } \\
\text { High yields of the } \\
\text { target compound }\end{array}$ \\
\hline PEF & $\begin{array}{l}\text { Chlorophylls } \\
\text { Carotenoids }\end{array}$ & $\begin{array}{l}\text { Nannochloropsis, } \\
\text { Chlorella vulgaris }\end{array}$ & $\begin{array}{ll}\text { - } & \text { Non-thermal treatment } \\
\text { - } & \text { No necessary solvents }\end{array}$ \\
\hline
\end{tabular}




\section{Supercritical Fluid Extraction (SFE)}

The extraction of high value compounds from algae is usually performed by organic solvents, but these solvents are mostly toxic and result in some pollution issue for environment. Supercritical fluid extraction (SFE) method appears as an alternative to solvent extraction for high value compounds of algae. In the view of environmental protection and recovery of valuable compounds, SFE is more attractive than traditional solvent extraction methods. SFE method has high selectivity by adjusting process conditions. However, SFE requires higher equipment costs compared to the conventional extraction process (Patil et al., 2011). This extraction method uses safe and non-flammable solvents that provide adjustable selectivity to a certain degree. The process conditions of SFE are maintained with respect to the physical properties of supercritical fluid. The supercritical fluid solvent properties may be adjusted by changing pressure and temperature. In case of fixing these conditions correctly, the supercritical fluid would be more sensitive to targeting compounds in a complex natural matrix. $\mathrm{CO}_{2}$ is mostly preferred solvent in SFE technique. However, only $\mathrm{CO}_{2}$ may not be able to extract the natural bioactive substances, which are mostly polar. In order to handle this issue high polarity co-solvents are added during extraction. These processes are carried out in the extractor. A SFE extractor is mainly made up solvent and modifier pumps, temperature-controlled extraction cell, pressure limiter and collecting vessel (Crampon et al., 2011).

SFE method has been used for different algae and seaweeds. These are extracted for getting carotenoids, chlorophylls, polyunsaturated fatty acids and polyphenols (Herrero et al., 2010). Carotenoids (lutein, neoxanthin, zeaxanthin, astaxanthin and $\beta$-carotene) were extracted from species of Scenedesmus using $\mathrm{CO}_{2}$ at $30 \mathrm{MPa}$ and $60^{\circ} \mathrm{C}$ with $10 \%$ ethanol as co-solvent (Abrahamsson et al., 2012). The expansion of the modifier was basic to build the measure of carotenoids recovered compared with the utilization of smooth $\mathrm{SC}-\mathrm{CO}_{2}$. It was accounted for that the most significant carotenoid to chlorophyll proportion in Scenedesmus obliquus extraction was carried out $25 \mathrm{MPa}$ and $60^{\circ} \mathrm{C}$ utilizing $7.7 \%$ ethanol as co-solvent (Guedes et al., 2013). Another important bioactive carotenoid found in algae is astaxanthin. It is very important to use it together with ethanol as a solvent to make accurate extraction of this carotenoid by SFE from Haematococcus pluvialis and Monoraphidium species. It is subjected to centrifugation after the use of acid such as $\mathrm{H}_{2} \mathrm{SO}_{4}$ or $\mathrm{HCl}$ to separate high-value astaxanthin pigment from chlorophyll (Pan et al., 2012; Fujii, 2012).

Solana et al. (2014) reported that Scenedesmus obliquus was a good source of polyunsaturated fats, especially $\alpha$-linolenic acid. The researchers tried to extract these compounds with SFE technique. They found the optimum extraction conditions of SFE as following; pressure of $15 \mathrm{MPa}$ and temperature of $45^{\circ} \mathrm{C}$ for $30 \mathrm{~min}$ with $5 \%$ ethanol as modifier. Similarly, ethanol was observed to be important to increase the recovery of docosahexaenoic acid (DHA) from Schizochytrium limacinum likewise utilizing $40^{\circ} \mathrm{C}$ moderate temperatures however $35 \mathrm{MPa}$ higher pressures (Tang et al., 2011). Furthermore, ultrasound treatment was also coupled to SFE to increase extraction efficiency and shorten the extraction time. Tang et al. (2016) reported that the needed extraction time was shortened the time by half by using the ultrasound-assisted SFE compared to alone SFE.

\section{Pressurized Liquid Extraction (PLE)}

Pressurized liquid extraction (PLE) technique is a new alternative method to the traditional extraction due to being timesaving and consuming low solvent advantages. PLE technique is performed at a temperature range of 25 to $200^{\circ} \mathrm{C}$ and under pressure is not exceed $20 \mathrm{MPa}$. These conditions provide the solvent keep up in the fluid state during the whole extraction procedure. Moreover, the extraction medium can reduce to effect of oxygen and light in PLE methods. In PLE technique, the temperature of solvents is raised to till their critical points, where the solvents are still in the liquid phase during the extraction process. In the event of water as solvent, PLE technique is also called subcritical water extraction (SWE), superheated water extraction or pressurized hot-water extraction. The general principles and instrumental requirements are not changed with solvent type (King, 2000).

Reported applications of PLE concerning algal biomass are summarized in Table 1. Carotenoids are the most focused high value compounds of algae for PLE method. This method was also highly efficient in the extraction of antioxidants, phenols, fatty acids, fucosterol. Some macroalgae and microalgae are known as producers of carotenoids. For examples, Dunaliella salina (green microalgae) is generally utilized at industrial level of $\beta$ carotene supply, where saltiness and light are the mostapplicable parameters for overproduction of this compound (Fernandez-Garcia et al., 2012). Many authors reported that PLE method diminishes the amount of solvent and operation period for extraction. According to the other methods, PLE method can be easily modified in terms of bioactive compounds to be extracted.

\section{Subcritical Water Extraction (SWE)}

Extraction of high value compounds from plant tissue or algae matrix, subcritical water extraction is used as one of the green extraction method. Zakaria and Kamal (2016) reported that the extraction method used water instead of organic solvent as the extraction medium which makes this method "green" and environmental friendly (Huie, 2002).

The extraction procedure included some stages that began with dispersion of solutes from the transition components to the surface. Then, the solute compounds will be moved into the dissolving agent and took after by the elution of the solute compounds out of the extraction section. SWE offers improvements in the mass transfer rate and enhances the permeability of solvent into the cells giving the advantages of higher extraction yields, shorter extraction times, and a minimal effect on the activity and structure of the bioactive compounds extracted (Zakaria and Kamal, 2016). The SWE 
procedure includes the utilization of water at temperatures higher than its boiling point under high pressure to keep up its fluid state. The temperature applied during extraction process significantly affects the extraction productivity and selectivity. The extraction processes were quite short for SWE compared to traditional extraction technique. However, degradation of targeting compounds may be observed due to applying high temperature for long extraction time. Rodriguez-Meizoso et al. (2010) extracted high value compounds that showed antioxidant and antimicrobial activity from Haematococcus pluvialis algae by using SWE. They found out that extraction yield and antioxidant activity highly changed with extraction medium temperature. In another study by Plaza et al. (2010), increasing the extraction temperature enhanced the antioxidant capacity of natural extracts in SWE method. In this manner, process time and temperature optimization is critical to develop the SWE procedure (Lebovka et al., 2016). As a result, a safe, rapid and efficient extraction can be obtained by SWE method using water as a solvent, which is ecofriendly.

\section{Ultrasound Assisted Extraction (UAE)}

Ultrasound assisted extraction method has been widely used to extract high value compounds from algae matrix (Koubaa et al., 2015). Working principles of ultrasonication consist of three main stages. The first step is about forming micro bubbles in the extraction medium. Then these bubbles vibrate and grow with absorbing ultrasonic energy. After reaching critical size, the cavitation of the bubbles generates substantial shear forces and disrupts the surrounding cells. This extraction technique is generally preferred due to short extraction time, high extraction yield, using low amounts of solvents, minimal damage for heat-sensitive compounds and high selectivity, besides low capital cost and being easily performed in food and pharmaceutical industry (Kadam et al., 2013; Barba et al., 2015; Ibanez et al., 2012). Furthermore, this extraction technique can be combined with microwave-assisted extraction (MAE) and SFE to improve extraction process.

There are many studies in the literature where UAE was selected to extract lipids from algae. Cravotto et al. (2008) found out that the lipid extraction yield of algae with UAE was considerably higher than convectional extraction method applied with Soxhlet equipment. Natarajan et al. (2014) also extracted lipids from algae Tetraselmis suecica and Nannochloropsis sp.; and Chlorella sp. by ultra-sonication after cultivation. They reported that cell disruption efficiency correlates well with ultra-sonication energy consumption. The UAE process condition is highly affected on extraction yield. Thus, Wang et al. (2011) investigated the process conditions of ultra-sonication and found that the highest taurine from Porphyra yezoensis yield was obtained with an extraction time of $38.3 \mathrm{~min}$, the use of $300 \mathrm{~W}$ ultrasonic power and an extraction temperature of $40.5^{\circ} \mathrm{C}$. It was also reported that the cell disruption rate was directly proportional to ultra-sonication power and biomass to solvent ratio. UAE has shown promising results with regard to the recovery of astaxanthin from other algae. Using UAE, the yield increased up to $55 \%$ to $60 \%$ from Haematococcus pluvialis compared to the conventional maceration method, even when different solvents were used (Zou et al., 2013).

\section{Microwave Assisted Extraction (MAE)}

Microwave assisted extraction (MAE) method is also one of green extraction method. In this extraction method microwave or electromagnetic energy, whose frequency changes from $300 \mathrm{MHz}$ to $300 \mathrm{GHz}$, is used to heat extraction medium (solvent) to gain valuable compounds from sample (Jain et al., 2009). Heating in microwave technology is applied to directly extraction medium, while convectional heating firstly heats vessel then heat transfers to extraction medium. This direct heating of solvent added some advantages to MAE such as reduction of extraction time, minimal damage to heat sensitive materials, high extraction yield and low solvent consumption. MAE follows several stages. Firstly, the targeted parts of the sample matrix cut out from rest part of sample at high temperature and under pressure and then, solvent diffused through sample matrix, and finally the targeted part of sample matrix passed to solvent (Alupului et al., 2012). Many researchers have agreed with MAE process at industrial scale will be caught on as one of green extraction of high value compounds in the future (Li et al., 2012; Tatke and Jaiswal, 2011).

MAE has been recommended as an effective and fast extraction method to recovery antioxidants, pigments from plants, spices, lipids from vegetables and algae (Cravotto et al., 2008; Xiao et al., 2009). In literature MAE technique is generally used to extract lipids from algae. Lee et al. (2010) compared different extraction techniques to separate algae lipids from biomass and found out that the highest extraction yield was obtained with MAE. Cravotto et al. (2008) reported that when extraction procedure applied with MAE, the required extraction time decreased a 10 -fold and extraction yield increased from $50 \%$ to $500 \%$ compared to conventional techniques. Pan et al. (2012) tried to extract lipids from 3 different algae species and compared MAE with convectional solvent extraction method. Their results indicated that microwave extraction enhanced the lipid extraction yield 15 times for Chlorella sorokiniana, several hundred percent for Nannochloropsis salina and over 10 times for Galdieria sulphuraria comparing to conventional method.

MAE method is also used to extract pigments from algae apart from lipids. Pasquet et al. (2011) determined the effect of MAE method on pigments (chlorophyll a and $\mathrm{b}, \beta$-carotene and fucoxanthin) extraction yield from algae Cylindrotheca closterium and Dunaliella tertiolecta. Their results indicated that MAE was the best extraction process for Cylindrotheca closterium pigments. Juin et al. (2015) also used MAE method to extract pigments of Porphyridium purpureum. Freeze dried biomass was treated to MAE to obtain phycoerythin, phycocyanin and allophycocyanin and the study concluded that MAE was fast and high yield process efficient to recovery these pigments. 


\section{Pulsed Electric Field (PEF)}

Pulsed electric field (PEF) is used to enhance the extraction yield of intercellular high value compounds obtained from algae. In addition to increasing yield, PEF allows to eliminate removing the water stage for fresh water algae. The working principle of the PEF was explained as cell membrane electropermeabilization or electroporation by electromechanical compression and electric field-induced tension in many studies (Luengo et al., 2014; Rego et al., 2015; Parniakov et al., 2015; Eing et al., 2013; Zbinden et al., 2013). Electroporation results in an increase in permeability of cell membrane to ions and macromolecules because of local defects or pores in the cell membrane (Parniakov et al., 2015). Barba et al. (2015) listed PEF as one of green extraction method apart from other methods mentioned previously in this paper. They also summarized the advantages of PEF to extract high value compounds from algae as follows; eliminating of toxic solvents usage, short extraction time, diminishing heating effect, selective extraction, and great protection of high value compounds.

PEF applications of algae have been considerably studied over last decades. Mostly, PEF technology was used to improve lipid extraction from algal biomass. Eing et al. (2013) demonstrated how PEF treatment worked selectively during extraction of lipids from algae. Moreover, they found out that lipid extraction yield was four times higher when algae biomass was treated with PEF compared to untreated samples. Zbinden et al. (2013) also tested the effect of PEF pretreatment on lipid extraction yield of Ankistrodesmus falcatus which was known as good lipid source. Their results showed that presence of electrical field helped to disturb cell membrane causing an increase in lipid recovery and a decrease in the required time to treat with solvent. The yield of fatty acids recovered from algae was also significantly increased with PEF treatment (Sheng et al., 2011). Toepfl et al. (2006) reported that PEF technology was feasible method for algae lipid extraction due to low energy consumption, potential to be scaled up and economic.

PEF assisted extraction was also used to extract pigments from algae. Luengo et al. (2014) investigated the effect of PEF treatments on the extraction of carotenoids and chlorophylls from Chlorella vulgaris and their results demonstrated that PEF treatment caused an increase in extraction yield of pigments and this extraction yield was highly dependent on electric field strength, treatment time and total elapsed time. Parniakov et al. (2015) also reported that algae pigments extraction enhanced obviously with PEF treatment.

\section{Comparison Green Extraction with Conventional Extraction}

High value bioactive compounds are generally extracted from algae by solvent extraction methods (Booth, 1969). Extraction takes too long time with conventional methods. This means that the duration of the process increases the amount of energy consumed. The disadvantages of conventional methods are unsafe and flammable solvents, potentially toxic emissions due to extraction, inexpensive and highly softening solvents, non-specific extraction, challenging and prolonged technique. For example, as a source of solvency, scientists are discovering new advances to reduce or eliminate the use of life in accordance with petroleum, the fossil assets of diminishing lives, the cost of living things and reducing $\mathrm{CO}_{2}$ discharges (Chemat et al., 2015). From the point of view of clean methods (SFE, UAE, SWE, PLE, MAE and PEF), for separating unsaturated fats from complex grids, have been created where they can be utilized routinely.

Conventional solvent extraction is widely used since the chemical solvents are relatively inexpensive and high lipid recovery yields can be achieved. Conventional solvent extraction is generally based on the concept of "like dissolves like". Several solvents have been proposed for the extraction of algae lipids, such as methanol/chloroform, hexane/isopropanol, hexane/ethanol, dichloromethane/ethanol etc. In those co-solvent systems, the polar alcohols disrupt the hydrogen bonding and electrostatic forces between the membrane-associated polar lipids and protein and make it porous. This enables the non-polar solvent (e.g.; chloroform, hexane) to enter the cell and interact with the hydrophobic neutral lipids. In other cases, pure solvents as 1-butanol, ethanol, hexane, etc. have also been tried. However, the extraction performances of pure alcohols are never more than 90\% of the yield obtained by the Bligh and Dyer (B and D) method. The Bligh and Dyer method can be used for lipid extraction from any tissue containing water up to $80 \%$.

There were many researches about comparison conventional extraction method with green extraction techniques. Such as conventional extraction method is in comparison with UAE about the extraction yield of DHA increased by $50-500 \%$ (Cravotto et al., 2008). Hu et al. (2011) revealed that PLE processes are faster and require smaller volumes of solvents compared to traditional extraction techniques. The extraction efficiency of polyphenols with PLE technique was higher than convectional extraction techniques (Tierney et al., 2013). Denery et al. (2004) also reported similar results about extraction efficiency of carotenoids from microalgae in PLE and traditional solvent extraction. Pasquet et al. (2011) used MAE as green extraction and cold and hot soaking as conventional extraction technique to extract pigments from algae and they found out that MAE showed better results than conventional methods with respect to extraction efficiency. Zakaria and Kamal (2016) explained the basis of faster extraction rate of SFE than conventional extraction method as being able to penetrate of solvent into porous solid materials more effectively in SFE. Thus, the extraction time could be reduced from hours or days in a liquid-solid extraction to a few tens of minutes in SFE. Ibanez et al. (2012) reported that the SFE method is superior when compared to the conventional extraction method and extraction is carried out without any residue in the extraction medium using $\mathrm{CO}_{2}$ as a co-solvent.

\section{Conclusion}

This review paper shows that green extraction techniques have potential to replace conventional 
extraction methods. Because green extraction techniques have begun to focus on new approaches for the extraction of high-value compounds due to the consumption of high quantities of hazardous solvents required and nonenvironmentally friendly approaches in conventional extraction method. SFE, PLE, SWE, UAE, MAE and PEF are the most commonly used techniques as green extraction method. Pigments, lipids, fatty acids, polysaccharides, antioxidants, minerals and other compounds exhibiting anti-microbial activity are successfully and efficiently extracted with these green extraction techniques. Recent studies have been shown that green extraction methods provide excellent alternatives against to traditional method -the amount of high value compounds produced and the quality are similar or even better. However, additional research are required in order to improve the pre-processing technology and the process of extraction itself. Innovative developments in green extraction techniques are studied to reduce the cost of extraction, the time consumed, laborious and higher selectivity of the downstream processes.

\section{References}

Abrahamsson V, Rodriguez-Meizoso I, Turner C. 2012. Determination of carotenoids in microalgae using supercritical fluid extraction and chromatography. J Chromatogr A., 1250:63-68. 10.1016/j.chroma.2012.05.069.

Alupului A, Calinescu I, Lavric V. 2012. Microwave extraction of active principles from medicinal plants. UPB Sci Bull Ser B., 74:1454-2331. ISSN 1454-2331.

Barba FJ, Grimi N, Vorobiev E. 2015. New approaches for the use of non-conventional cell disruption technologies to extract potential food additives and nutraceuticals from microalgae. Food Eng Rev., 7:45-62. DOI: 10.1007/s12393014-9095-6.

Barba FJ, Zhu Z, Koubaa M, Sant'Ana AS, Orlien V. 2016. Green alternative methods for the extraction of antioxidant bioactive compounds from winery wastes and by-products: A review. Trends Food Sci Technol., 49:96-109. doi.org/10.1016/j.tifs.2016.01.006.

Booth E. 1969. The manufacture and properties of liquid seaweed extracts. in Proc Int Seaweed Symp., 6:655-662.

Chemat F, Fabiano-Tixier AS, Vian MA, Allaf T, Vorobiev E. 2015. Solvent-free extraction of food and natural products. TrAC Trends Anal Chem., 71:157-168. DOI.org/10.1016/j.trac.2015.02.021.

Chemat F, Vian MA, Cravotto G. 2012. Green extraction of natural products: concept and principles. Int J Mol Sci., 13:8615-8627. DOI: 10.3390/ijms13078615.

Crampon C, Boutin O, Badens E. 2011. Supercritical carbon dioxide extraction of molecules of interest from microalgae and seaweeds. Ind Eng Chem Res., 50: 8941-8953.

Cravotto G, Boffa L, Mantegna S, Perego P, Avogadro M, Cintas P. 2008. Improved extraction of vegetable oils under high-intensity ultrasound and/or microwaves. Ultrason Sonochem., 902.DOI.org/10.1016/j.ultsonch.2007.10.009.

Cuellar-Bermudez SP, Aguilar-Hernandez I, Cardenas-Chavez DL, Ornelas-Soto N, Romero-Ogawa MA, Parra-Saldivar R. 2015. Extraction and purification of high-value metabolites from microalgae: essential lipids, astaxanthin and phycobiliproteins. Microb Biotechnol., 8(2):190-209. DOI: 10.1111/1751-7915.12167.
Denery JR, Dragull K, Tang CS, Li QX. 2004. Pressurized fluid extraction of carotenoids from Haematococcus pluvialis and Dunaliella salina and kavalactones from Piper methysticum. Anal Chim Acta., 501:175-181. DOI.org/10.1016/ j.aca.2003.09.026.

Eing C, Goettel M, Straessner R, Gusbeth C, Frey W. 2013. Pulsed electric field treatment of microalgae-benefits for microalgae biomass processing. IEEE Trans Plasma Sci., 41:2901-2907. DOI: 10.1109/TPS.2013.2274805.

Eriksen J. 2016. Research Trends in the Dominating Microalgal Pigments, $\beta$-carotene, Astaxanthin, and Phycocyanin Used in Feed, in Foods, and in Health Applications. Nutr Food Sci., 6:507. doi:10.4172/2155-9600.1000507.

Fernández-García E, Carvajal-Lérida I, Jarén-Galán M, GarridoFernández J, Pérez-Gálvez A, Hornero-Méndez D, 2012. Carotenoids bioavailability from foods: From plant pigments to efficient biological activities. Food Res Int., 46:438-450. DOI.org/10.1016/j.foodres.2011.06.007.

Fujii K. 2012. Process integration of supercritical carbon dioxide extraction and acid treatment for astaxanthin extraction from a vegetative microalga. Food Bioprod Process., 90:762-766.DOI.org/10.1016/j.fbp.2012.01.006.

Guedes AC, Giao MS, Matias AA, Nunes AVM, Pintado ME, Duarte CMM. 2013. Supercritical fluid extraction of carotenoids and chlorophylls a, b and c, from a wild strain of Scenedesmus obliquus for use in food processing. J Food Eng., 116:478-482. DOI.org/10.1016/j.jfoodeng.2012. 12.015.

Herrero M, Mendiola JA, Cifuentes A, Ibáñez E. 2010. Supercritical Fluid Extraction: Recent Advances And Applications. Journal of Chromatography A., 1217(16): 2495-2511.DOI: 10.1021/ie102297d.

Hu J, Guo Z, Glasius M, Kristensen K, Xiao L, Xu X. 2011. Pressurized liquid extraction of ginger (Zingiber officinale Roscoe) with bioethanol: An efficient and sustainable approach. J Chromatogr A., 1218:5765-5773. DOI.org/10.1016/j.chroma.2011.06.088.

Huie CW, 2002. A review of modern sample-preparation techniques for the extraction and analysis of medicinal plants. Anal Bioanal Chem., 373:23-30. DOI: 10.1007/s00216-002-1265-3.

Ibanez E, Herrero M, Mendiola JA, Castro-Puyana M. 2012. Extraction and characterization of bioactive compounds with health benefits frommarine resources:Macro and micro algae, cyanobacteria, and invertebrates, in: Hayes, M. (Ed.), Marine Bioactive Compounds: Sources, Characterization and Applications, Springer Science Business Media. LLC, New York., 55-98. DOI:10.1007/978-1-4614-1247-2_2.

Jain T, Jain V, Pandey R, Vyas A, Shukla SS. 2009. Microwave assisted extraction for phytoconstituents-an overview. Asian J Res Chem., AJRC 2:19-25.

Juin C, Chérouvrier JR, Thiéry V, Gagez AL, Bérard JB, Joguet N, Kaas R, Cadoret JP, Picot L. 2015. Microwave-assisted extraction of phycobiliproteins from Porphyridium purpureum. Appl Biochem Biotechnol., 175:1-15. DOI: 10.1007/s12010-014-1250-2.

Kadam SU, Tiwari BK, O'Donnell CP. 2013. Application of novel extraction technologies for bioactives from marine algae. J Agric Food Chem., 61:4667-4675. DOI: $10.1021 / \mathrm{jf} 400819 \mathrm{p}$.

King JW. 2000. Advances in critical fluid technology for food processing. Food Sci Technol Today., 14: 186-91.

Koubaa M. Roselló-Soto E, Šic Žlabur J, Režek Jambrak A, Brnčić M, Grimi N, Boussetta N, Barba FJ. 2015. Current and new insights in the sustainable and green recovery of nutritionally valuable compounds from Stevia rebaudiana Bertoni. J Agric Food Chem., 63:6835-6846. DOI: 10.1021/acs.jafc.5b01994.

Lebovka N, Vorobiev E, Chemat F. 2016. Enhancing extraction processes in the food industry. CRC Press. Reference - 570 Pages - 150 B/W Illustrations ISBN 9781138199330. 
Lee J, Lee Y, Yoo C, Jun S, Jun Y, Ahn C, Ahn Y, Oh H, Oh M. 2010. Comparison of several methods for effective lipid extraction from microalgae. Bioresour Technol., 101:75-77. DOI.org/10.1016/j.biortech.2009.03.058.

Li Y, Radoiu M, Fabiano-Tixier A, Fabiano-Tixier S, Chemat F. 2012. From laboratory to industry: scale-up, quality, and safety consideration for microwave-assisted extraction, In F. Chemat, \& G. Cravotto (Eds.), Microwave-assisted extraction for bioactive compounds., 207-229.DOI 10.1007/978-1-4614-4830-3.

Luengo E, Condón-Abanto S, Álvarez I, Raso J. 2014. Effect of pulsed electric field treatments on permeabilization and extraction of pigments from Chlorella vulgaris. J Membr Biol., 247:1269-1277. DOI: 10.1007/s00232-014-9688-2.

Natarajan R, Ang WMR, Chen X, Voigtmann M, Lau R. 2014. Lipid releasing characteristics of microalgae species through continuous ultrasonication. Bioresour Technol., 158:7-11. DOI.org/10.1016/j.biortech.2014.01.146.

Pan JL, Wang H, Wang M, Chen C, Chen Y, Chang J, Chang S. 2012. Extraction of astaxanthin from Haematococcus pluvialis by supercritical carbon dioxide fluid with ethanol modifier. Eng Life Sci., 12:638-647.DOI.org/10.1002/ elsc. 201100157.

Parniakov O, Apicella E, Koubaa M, Barba FJ, Grimi N, Lebovka N, Pataroc G, Ferraric G, Vorobiev E. 2015. Ultrasound-assisted green solvent extraction of high-added value compounds from microalgae Nannochloropsis spp. Bioresour Technol., 198:262-267. DOI.org/10.1016/ j.biortech.2015.09.020.

Pasquet V, Chérouvrier JR, Farhat F, Thiéry V, Piot JM, Bérard JB, Kaas R, Seriveb B, Patricec T. Cadoretb JP, Picot L. 2011. Study on the microalgal pigments extraction process: Performance of microwave assisted extraction. Process Biochem., 46:59-67. DOI.org/10.1016/ j.procbio.2010.07.009.

Patil PD, Gude VG, Mannarswamy A, Deng S, Cooke P, Munson-McGee S, Rhodes I, Lammers P, Nirmalakhandan N. 2011. Optimization of direct conversion of wet algae to biodiesel under supercritical methanol conditions. Bioresour Technol., 102:118-122. DOI: 10.1021/jf400819p.

Plaza M, Amigo-Benavent M, Del Castillo MD, Ibáñez E, Herrero M. 2010. Facts about the formation of new antioxidants in natural samples after subcritical water extraction. Food Res Int., 43:2341-2348. DOI.org/ 10.1016/j.foodres.2010.07.036.

Plaza M, Santoyo S, Jaime L, Avalo B, Cifuentes A, Reglero G. 2012. Comprehensive characterization of the functional activities of pressurized liquid and ultrasound-assisted extracts from Chlorella vulgaris. LWT-Food Sci Technol., 46:245-253. DOI:10.1016/j.lwt.2011.09.024.

Rego D, Costa L, Pereira MT, Redondo LM. 2015. Cell membrane permeabilization studies of chlorella sp. by pulsed electric fields. IEEE Trans Plasma Sci., 43:34833488. DOI: 10.1109/TPS.2015.2448660.

Rodríguez-Meizoso I, Jaime L, Santoyo S, Señoráns FJ, Cifuentes A, Ibáñez E. 2010. Subcritical water extraction and characterization of bioactive compounds from Haematococcus pluvialis microalga. J Pharm Biomed Anal., 51:456-463. DOI.org/10.1016/j.jpba.2009.03.014.
Sheng J, Vannela R, Rittmann BE. 2011. Evaluation of celldisruption effects of pulsed-electric-field treatment of Synechocystis PCC 6803. Environ Sci Technol., 45:37953802. DOI: 10.1021/es103339x.

Solana M, Rizza CS, Bertucco A. 2014. Exploiting microalgae as a source of essential fatty acids by supercritical fluid extraction of lipids: Comparison between Scenedesmus obliquus, Chlorella protothecoides and Nannochloropsis salina. J Supercrit Fluids., 92:311-318.DOI.org/10.1016/ j.supflu.2014.06.013.

Tang S, Qin C, Wang H, Li S, Tian S. 2011. Study on supercritical extraction of lipids and enrichment of DHA from oil-rich microalgae. J Supercrit Fluids., 57:44-49. DOI.org/10.1016/j.supflu.2011.01.010.

Tatke P, Jaiswal Y. 2011. An overview of microwave assisted extraction and its applications in herbal drug research. Res $\mathbf{J}$ Med Plant., 5:21-31. DOI: 10.3923/rjmp.2011.21.31.

Tierney MS, Smyth TJ, Hayes M, Soler-Vila A, Croft AK, Brunton N. 2013. Influence of pressurised liquid extraction and solid-liquid extraction methods on the phenolic content and antioxidant activities of Irish macroalgae. Int J Food Sci Technol., 48:860-869. DOI.org/10.1111/ijfs.12038.

Toepfl S, Mathys A, Heinz V, Knorr D. 2006. Review: potential of high hydrostatic pressure and pulsed electric fields for energy efficient and environmentally friendly food processing. Food Rev Int., 22:405-423. DOI.org/ 10.1080/87559120600865164.

Wang B, Tong GZ, Qu YL, Li L. 2011. Microwave-assisted extraction and in vitro antioxidant evaluation of polysaccharides from Enteromorpha prolifera. Applied mechanics and Materials., 79:204-209. DOI.org/10.4028/ www.scientific.net/AMM.79.204.

Xiao XH, Wang JX, Wang G, Wang JY, Li GK. 2009. Evaluation of vacuum microwave-assisted extraction technique for the extraction of antioxidants from plant samples. J Chromatogr A., 1216:8867-8873. DOI.org/ 10.1016/j.chroma.2009.10.087.

Yen HW, Hu IC, Chen CY, Ho SH, Lee DJ, Chang JS. 2013. Microalgae-based biorefinery-from biofuels to natural products. Bioresour Technol., 135: 166-174. DOİ.org/ 10.1016/j.biortech.2012.10.099.

Zakaria SM, Kamal SMM, 2016. Subcritical water extraction of bioactive compounds from plants and algae: applications in pharmaceutical and food ingredients. Food Eng Rev., 8:2334. DOI: 10.1007/s12393-015-9119-x.

Zbinden MDA, Sturm BS, Nord RD, Carey WJ, Moore D, Shinogle H, Stagg-Williams SM. 2013. Pulsed electric field $(\mathrm{PEF})$ as an intensification pretreatment for greener solvent lipid extraction from microalgae. Biotechnol Bioeng., 110:1605-1615. DOI: 10.1002/bit.24829.

Zou T, Zou B, Jia Q, Li H, Li W, Wang C, Wang X, Wu H, Wu F. 2013. Response surface methodology for ultrasoundassisted extraction of astaxanthin from Haematococcus pluvialis. Mar Drugs., 11:1644-1655. DOI: 10.3390/ md11051644. 